\title{
A STUDY OF PEOPLE LIVING WITH HIV-AIDS [PLHA] ON FIRST LINE HIGHLY ACTIVE ANTI- RETROVIRAL THERAPY [HAART] WITH IMMUNOLOGICAL FAILURE
}

Natarajan Kandasamy1, Vijayanand Radhakrishnan², Ashokkumar Subramanian ${ }^{3}$, Ravichandran Narayanan ${ }^{4}$,
Mohamed Kalifa Adbul Muthalif5, Namitha Narayanan', Ramalingam Arunachalam ${ }^{7}$, Marimuthu Arumugam ${ }^{8}$

${ }_{1}^{1}$ Associate Professor, Department of Internal Medicine, Government Stanley Medical College.

${ }^{2}$ Assistant Professor, Department of Internal Medicine, Government Stanley Medical College.

${ }^{3}$ Associate Professor, Department of Internal Medicine, Government Stanley Medical College.

${ }^{4}$ Assistant Professor, Department of Internal Medicine, Government Stanley Medical College.

${ }_{5}^{5}$ Assistant Professor, Department of Internal Medicine, Government Stanley Medical College.

${ }^{6}$ Assistant Professor, Department of Internal Medicine, Government Stanley Medical College.

${ }^{7}$ Assistant Professor, Department of Internal Medicine, Government Stanley Medical College.

${ }^{8}$ Assistant Professor, Department of Internal Medicine, Government Stanley Medical College.

ABSTRACT

\section{BACKGROUND}

Follow-up of patients with First line antiretroviral therapy, Cluster Differentiation (CD4) counts are done every 6 months. Viral load is not possible in resource poor settings like India. Non-Governmental Organisation (NGO's), Human Immunodeficiency Virus (HIV) treating physicians and international guidelines recommend viral load as the follow-up method for first line failure, so to study the impact of national program with immunological criteria and its sensitivity to identify virological failure is needed at this juncture.

\section{METHODS}

A total of 170 patients from northern districts of Tamilnadu referred to Government Hospital for Thoracic Medicine (GHTMTambaram Sanatorium) State AIDS Clinical Expert Panel (SACEP) committee with suspected first line ART failure were included in the study [after fulfilling the inclusion and exclusion criteria]. Viral load done for these patients were compared with Immunological criteria for concordance or discordance.

\section{RESULTS}

In our study we conclude that Virological discordance was noted in 51\% of all cases. CD4 falling greater than 50\% of on treatment peak value has the highest sensitivity to detect virological failure. The ODD's ratio for immunological criteria CD4 falling more than $50 \%$ was three times more than other criteria with significant P-value 0.002 . Immunological criteria CD4 persistently below 100 had highest specificity.

\section{CONCLUSION}

Immunological criteria CD4 falling more than 50\% had highest sensitivity. 2. Immunological criteria CD4 persistently below 100 had had highest specificity. 3. The ODD's ratio for immunological criteria CD4 falling more than $50 \%$ of on treatment peak value was three times more than other criteria with significant P-value 0.002 . 4. Immunological and virological discordance was $51 \%$ of all cases. 5. Differences in age and duration of ART was not associated with virological failure between males and females. 6. An economical lab test with low cost to detect the viral load is the need of the hour.

\section{KEYWORDS}

PLHA, Immunological Failure, Virological Failure, Immunovirological Discordance.

HOW TO CITE THIS ARTICLE: Kandasamy N, Radhakrishnan V, Subramanian A, et al. A study of people living with HIV-aids [PLHA] on first line highly active anti-retroviral therapy [HAART] with immunological failure. J. Evolution Med. Dent. Sci. 2016;5(56):38723876, DOI: $10.14260 /$ jemds/2016/886

\section{INTRODUCTION}

In India, National AIDS Control Organization (NACO) under Health and Family Welfare Department, Government of India is the coordinating body for the care and support of People Living with HIV AIDS (PLHA). The first line Anti-Retroviral Therapy (ART) was started on April 2004.(1) Second line ART.(2) for patients who were failing first line was started in January 2008. Centres of excellence screens the ART patients

Financial or Other, Competing Interest: None.

Submission 21-05-2016, Peer Review 01-07-2016,

Acceptance 07-07-2016, Published 14-07-2016.

Corresponding Author:

Dr. Vijayanand Radhakrishnan,

Assistant Professor,

Department of Internal Medicine,

Government Stanley Medical College.

E-mail: rva711@yahoo.co.in

DOI: $10.14260 /$ jemds $/ 2016 / 886$ for virological failure and advises for initiation of second line ART.

First line ART is the treatment given for an ART naïve patient when he satisfies the national clinical and laboratory criterion to initiate ART. Second line ART is the next regimen used in succession when first-line therapy fails. 2 Nucleotide Reverse Transcriptor Inhibitor (NRTI) and 1 Non-Nucleotide Reverse Transcriptor Inhibitor (NNRTI) is used for 1st line treatment as per NACO guidelines during the study period. Treatment failure (2) can be clinical failure, immunological failure and virological failure.

1. Clinical failure is suspected if there is new or recurrent WHO Stage 4 condition after 6 months of ART with $95 \%$ adherence.

2. Immunological failure is suspected when

- $\quad$ CD4 falls below baseline. 
- CD4 count falls greater than 50\% from on treatment peak value.

- When CD4 count remains persistently below 100 cells/mm.

3. Virological failure when viral load is greater than 1000 copies/mL.

Of the three failures, virological failure is the most earliest failure and viral load test.(3) is the most sensitive test to detect treatment failure early. National AIDS Control Program (NACP) does not use the viral load as the test for follow-up of patients on first line ART due to cost. They follow the patents with CD4 every six months. They suspect treatment failure by immunological failure by the above three criteria said above.

These patients were screened for viral load and started second line of viral load; is more than 1000 copies $/ \mathrm{mL}$.

This study was undertaken to analyse patients with immunological failure by any one of above criteria and the relationship between the criteria and virological failure and immunological virological discordance.

\section{MATERIALS AND METHODS: \\ Objective}

To analyse the patients on first line ART who are having immunological failure with any one immunological criteria.

To study the sensitivity, specificity, positive and negative predictive values of each criterion to virological failure.

To study the immunological and virological discordance in these patients.

\section{Source of Data}

All patients with immunological failure with any one of immunological criteria were included in the study from a tertiary care centre in Chennai from a period of March 2011 to February 2012. The patients must have had at least 6 months of ART with more than $95 \%$ adherence, were included in the study.

\section{Duration of Study}

12 months [March 2011-Feb. 2012]

\section{Inclusion Criteria}

- ART naïve patients

- Minimum of 6-month ART

- Patients with more $95 \%$ adherence to treatment in last 6 months.

\section{Exclusion Criteria}

Patients who had ART before registering in the national program.

\section{Type of Study}

Prospective cross-sectional study.

\section{METHODS}

All patients on first line ART for more than six months with more than $95 \%$ adherence with one positive immunological criterion were included in the study.

With the consent from the patient, data was collected and tabulated. Viral load is done for these eligible patients. If patient has viral load more than 1000 copies/mL, he is taken as patient with treatment failure. If viral load is less than 1000 copies per $\mathrm{mL}$ they are not considered to have treatment failure. Patients with treatment failure were started on second line ART.

\section{RESULTS}

- Total cases studied 170 .

- Table 1 tabulates sex distribution of outcomes.

\begin{tabular}{|c|c|c|c|}
\hline Sl. No. & Sex Distribution & Frequency & Percentage \\
\hline \multirow{4}{*}{1} & \multicolumn{3}{|c|}{ All patients } \\
\hline & Female & 45 & 26.47 \\
\hline & Male & 125 & 73.53 \\
\hline & Total & 170 & 100 \\
\hline \multirow{4}{*}{2} & \multicolumn{3}{|c|}{ With Virological Failure } \\
\hline & Female & 15 & 18.29 \\
\hline & Male & 67 & 81.71 \\
\hline & Total & 82 & 100 \\
\hline \multirow{4}{*}{3} & \multicolumn{3}{|c|}{ With Immunological Virological Discordance } \\
\hline & Female & 30 & 34.09 \\
\hline & Male & 58 & 65.91 \\
\hline & Total & 88 & 100 \\
\hline \multicolumn{4}{|c|}{ Table 1: Sex Distribution } \\
\hline
\end{tabular}

\begin{tabular}{|c|c|c|c|}
\hline Index & $\begin{array}{c}\text { Frequ } \\
\text { ency }\end{array}$ & $\begin{array}{c}\text { [95\% Conf. } \\
\text { Interval] }\end{array}$ & $\begin{array}{c}\text { Perce } \\
\text { ntage }\end{array}$ \\
\hline Virological failure & 82 & $\begin{array}{c}69.10046 \\
94.89954\end{array}$ & 48.2 \\
\hline $\begin{array}{c}\text { Immunological and } \\
\text { virological discordance }\end{array}$ & 88 & $\begin{array}{c}75.10046 \\
100.8995\end{array}$ & 51.7 \\
\hline Table 2: Frequency of Virological Failure and Immuno- \\
Virological Discordance \\
\hline
\end{tabular}

TABLE 3: Tabulates the mean age distribution virological failure and immuno-virological discordance.

\begin{tabular}{|c|c|c|c|}
\hline $\begin{array}{l}\text { Sl. } \\
\text { No. }\end{array}$ & Index & $\begin{array}{c}\text { Mean } \\
\text { Age }\end{array}$ & $\begin{array}{c}\text { 95\% Confidence } \\
\text { Interval }\end{array}$ \\
\hline \multirow{4}{*}{1} & \multicolumn{3}{|c|}{ All patients } \\
\hline & $\begin{array}{c}\text { All } \\
\text { patients }\end{array}$ & 38.43 & $37.15,39.71$ \\
\hline & Female & 36.33 & $33.46,39.20$ \\
\hline & Male & 39.19 & $37.80,40.57$ \\
\hline \multirow{4}{*}{2} & \multicolumn{3}{|c|}{ With Virological Failure } \\
\hline & $\begin{array}{c}\text { All } \\
\text { patients }\end{array}$ & 37.92 & $36.41,39.43$ \\
\hline & Female & 36.2 & $32.50,39.89$ \\
\hline & Male & 38.31 & $36.67,39.95$ \\
\hline \multirow{4}{*}{3} & \multicolumn{3}{|c|}{ With Immunological Virological Discordance } \\
\hline & $\begin{array}{c}\text { All } \\
\text { patients }\end{array}$ & 38.9 & $36.84,40.97$ \\
\hline & Female & 36.4 & $32.46,40.33$ \\
\hline & Male & 40.2 & $37.90,42.50$ \\
\hline \multicolumn{4}{|c|}{ Table 3: Mean Age Distribution } \\
\hline
\end{tabular}

One-sample t test for mean age of sample studied and mean age of patients with virological failure and mean age of patients with immuno-virological discordance did not show 
any relationship of age with virological failure (P-value 0.5) and immuno-virological discordance (P-value 0.6). Age does not play any role in predicting virological failure and immuno-virological discordance with immunological criteria.

\begin{tabular}{|c|c|c|c|}
\hline \multirow{2}{*}{$\begin{array}{c}\text { Sl. } \\
\text { No. }\end{array}$} & Index & $\begin{array}{c}\text { Mean Duration } \\
\text { of ART in } \\
\text { Months }\end{array}$ & $\begin{array}{c}\text { 95\% } \\
\text { Confidence } \\
\text { Interval }\end{array}$ \\
\hline \multirow{4}{*}{1 All Patients } \\
\hline \multirow{2}{*}{1} & All patients & 46.25 & $43.55,48.96$ \\
\cline { 2 - 4 } & Female & 48.93 & $43.6,54.25$ \\
\cline { 2 - 4 } & Male & 45.29 & $42.15,48.43$ \\
\hline \multicolumn{4}{|c|}{ With Immunological Virological Discordance } \\
\hline 5 & All patients & 46.13 & $41.95,50.31$ \\
\hline 6 & Female & 52.3 & $45.45,59.14$ \\
\hline 7 & Male & 42.94 & $37.84,48.05$ \\
\hline \multicolumn{4}{|c|}{ With Virological Failure } \\
\hline 9 & All patients & 46.39 & 42.9849 .79 \\
\hline 10 & Female & 42.2 & $34.82,49.57$ \\
\hline 11 & Male 47.32 & $43.51,51.14$ \\
\hline Table 4: Gives Mean Duration of ART in Patients with \\
Virological Failure and Immuno-Virological \\
\multicolumn{4}{|c|}{ Discordance. } \\
\hline \multicolumn{4}{|c|}{ Mean Duration of ART in Months } \\
\hline
\end{tabular}

Two-sample ' $\mathrm{t}$ ' test for mean duration of ART with virological failure and immuno-virological discordance did not show any relationship (P-value 0.9). Duration of ART has no role in virological failure and immuno-virological discordance.

Table 5: Tabulates the association of each criteria in frequency and percentage with virological failure and immuno-virological discordance.

\begin{tabular}{|c|c|c|c|}
\hline Statistic & $\begin{array}{c}\text { CD4 } \\
\text { Falling } \\
\text { More } \\
\text { Than } \\
\mathbf{5 0 \%}\end{array}$ & $\begin{array}{c}\text { CD4 } \\
\text { Falling } \\
\text { Below } \\
\text { Baseline }\end{array}$ & $\begin{array}{c}\text { CD4 } \\
\text { Persistently } \\
\text { Below 100 }\end{array}$ \\
\hline $\begin{array}{c}\text { Frequency of } \\
\text { criteria }\end{array}$ & 138 & 100 & 27 \\
\hline $\begin{array}{c}\text { Percentage of } \\
\text { criteria }\end{array}$ & $81.17 \%$ & $58.80 \%$ & $15.88 \%$ \\
\hline $\begin{array}{c}\text { Percentage of } \\
\text { virological failure in } \\
\text { the criteria }\end{array}$ & $92.60 \%$ & $56.09 \%$ & $19.50 \%$ \\
\hline $\begin{array}{c}\text { Percentage of } \\
\text { immuno-virological } \\
\text { discordance in the } \\
\text { criteria }\end{array}$ & $70.45 \%$ & $61.36 \%$ & $12.50 \%$ \\
\hline \multicolumn{2}{|c|}{ Table 5: Frequency and Percentage of Criteria (n=170) } \\
\hline
\end{tabular}

TABLE 6: Reveals the ODD's ratio, sensitivity and specificity of each criteria and virological failure and immunovirological discordance.

\begin{tabular}{|c|c|c|c|c|c|c|}
\hline Index & \multicolumn{3}{|c|}{ Virological Failure } & \multicolumn{3}{c|}{ Immuno-Virological Discordance } \\
\hline Statistic & $\begin{array}{c}\text { CD4 Falling } \\
\text { More Than } \\
\mathbf{5 0 \%}\end{array}$ & $\begin{array}{c}\text { CD4 Falling } \\
\text { Below } \\
\text { Baseline }\end{array}$ & $\begin{array}{c}\text { CD4 Persistently } \\
\text { Below 100 }\end{array}$ & $\begin{array}{c}\text { CD4 Falling } \\
\text { More Than } \\
\mathbf{5 0} \%\end{array}$ & $\begin{array}{c}\text { CD4 Falling } \\
\text { Below } \\
\text { Baseline }\end{array}$ & $\begin{array}{c}\text { CD4 Persistently } \\
\text { Below 100 }\end{array}$ \\
\hline Sensitivity & $91.46 \%$ & $56.10 \%$ & $19.51 \%$ & $70.45 \%$ & $61.36 \%$ & $12.50 \%$ \\
\hline & $29.55 \%$ & $38.64 \%$ & $87.50 \%$ & $8.54 \%$ & $43.90 \%$ & $80.49 \%$ \\
\hline $\begin{array}{c}\text { Specificity } \\
\text { Positive } \\
\text { Likelihood Ratio }\end{array}$ & 1.3 & 0.91 & 1.56 & 0.77 & 1.09 & 0.64 \\
\hline $\begin{array}{c}\text { Positive } \\
\text { Predictive Value }\end{array}$ & $54.74 \%$ & 4.14 & 0.92 & 3.46 & 0.88 & 1.09 \\
\hline $\begin{array}{c}\text { Negative } \\
\text { Predictive Value }\end{array}$ & $78.79 \%$ & $48.24 \%$ & $51.76 \%$ & $51.76 \%$ & $51.76 \%$ \\
\hline \multicolumn{7}{|c|}{ Table 6: ODD's Ratio, Sensitivity and Specificity and Other Values for Each Criteria and Outcome } \\
\hline
\end{tabular}

CD4 falling more than 50\% criteria has high sensitivity for both finding virological failure (91\%) and immuno-virological discordance (70\%). CD4 persistently below 100 criteria has high specificity for both finding virological failure (87\%) and immunovirological discordance $(80 \%)$. CD4 falling more than $50 \%$ criteria has high negative predictive $(78 \%)$ value in ruling out virological failure.

\begin{tabular}{|c|c|c|c|c|c|c|c|c|c|c|c|c|}
\hline & \multicolumn{6}{|c|}{ Virological Failure } & \multicolumn{6}{|c|}{ Immuno-Virological Discordance } \\
\hline Index & $\begin{array}{c}\text { CD4 } \\
\text { Falling } \\
\text { More } \\
\text { Than } \\
\mathbf{5 0 \%}\end{array}$ & $\begin{array}{c}\text { P- } \\
\text { value }\end{array}$ & $\begin{array}{c}\text { CD4 } \\
\text { Falling } \\
\text { Below } \\
\text { Baseline }\end{array}$ & $\begin{array}{c}P- \\
\text { value }\end{array}$ & $\begin{array}{c}\text { CD4 } \\
\text { Persistently } \\
\text { Below } 100\end{array}$ & $\begin{array}{c}P \text { - } \\
\text { value }\end{array}$ & $\begin{array}{c}\text { CD4 } \\
\text { Falling } \\
\text { More } \\
\text { Than } \\
\mathbf{5 0 \%}\end{array}$ & $\begin{array}{c}\text { P- } \\
\text { value }\end{array}$ & $\begin{array}{c}\text { CD4 } \\
\text { Falling } \\
\text { Below } \\
\text { Baseline }\end{array}$ & $\begin{array}{c}P \text { - } \\
\text { value }\end{array}$ & $\begin{array}{c}\text { CD4 } \\
\text { Persistently } \\
\text { Below } 100\end{array}$ & $\begin{array}{c}P- \\
\text { value }\end{array}$ \\
\hline $\begin{array}{l}\text { Odd's } \\
\text { Ratio }\end{array}$ & 4.49 & 0.0004 & 0.8 & 0.29 & 1.69 & 0.14 & 0.22 & 0.0004 & 1.2 & 0.29 & 0.58 & 0.14 \\
\hline
\end{tabular}


Below baseline criteria can predict one and a half times immuno-discordance more than virological failure. CD4 falling more than $50 \%$ of peak value identifies virological failure 20 times than immuno-virological discordance. CD4 below hundred persistently identifies virological failure 3 times than immuno-virological discordance.

\section{DISCUSSION}

In one of the studies in Nigeria.(4) where the virological failures and immuno-virological discordance was $33 \%$ at the end of one year. Here in this study we see $51 \%$ of immuno-virological discordance with mean duration of ART of 46 months. Nigerian study included all the cases on first line ART at 12 months. In this study the patients with suspected treatment failure with immunological criteria were included. The duration of ART might have an impact on the high immunovirological discordance.

In another study in Nigeria.(5) which found that immunological criteria has poor prediction of virological failure. The study showed the sensitivity of immunological criteria to detect viral failure was $58 \%$, specificity was $75 \%$ and the positive-predictive value was $39 \%$. In this study, the sensitivity was studied for each individual criteria which varied between 20 to $91 \%$. CD4 falling more than $50 \%$ criteria had high sensitivity of $91 \%$ for finding virological failure. CD4 persistently below 100 criteria had low sensitivity of $19 \%$ for finding virological failure. The specificity for each criterion, which varied between 29 to $87 \%$ for virological failure. CD 4 persistently below 100 criteria has high specificity of $87 \%$ for finding virological failure.

The positive predictive value for each individual criteria, which varied between 46 to $59 \%$ for virological failure which was higher than the Nigerian study. CD4 persistently below 100 criteria had high positive predictive value of $59 \%$ for finding virological failure. We see individual criterion CD4 falling more than $50 \%$ criteria had high sensitivity for predicting virological failure rather than all three together. CD4 persistently below 100 had lowest sensitivity for predicting virological failure rather than all three together. Reasons may be the frequencies of each criterion. We see the frequency of CD 4 falling more than $50 \%$ was $81 \%$ of cases. As the CD4 count to initiate the HAART was less than 350 cells \% and with TB irrespective of CD4 count we naturally have more frequency of CD4 falling more than $50 \%$ than the other two.

In a Sub-Saharan.(6) multicentric study the viral load when used for follow-up picked virological failure three times more than when followed by CD 4 criteria, earlier shifting with high mean CD4 of 215. In this study we see the immunological criteria when used had only $49 \%$ virological failure.

In another Columbian Carribean city.(7) study of treatment failure revealed virological failure was most frequent (20.9\%) followed by immunological (14.0\%) and clinical failure (4.7\%). It shows only two-thirds of the virological failures are detected by immunological criteria. This study which shows only half of the total cases with immunological criteria had virological failure.

In another study in Kenyan.(8) also found that immunological and clinical failure had poor prediction of virological failure. The study showed the sensitivity of immunological and clinical failure to detect viral failure was $36.4 \%$, specificity was $83.5 \%$ and the positive-predictive value was $12.3 \%$. In this study the sensitivity was studied for each individual criteria which varied between 20 to $91 \%$, specificity was between 29 to $87 \%$ and positive predictive value was 46 to $59 \%$ which was higher.

In a very similar study in India in Chennai and same setting.(9) predicting virological failure with immunological failure showed $62 \%$ had virological failure, which was higher than this study. The sensitivity was higher ranging between 60 to $80 \%$ for each criterion, which was higher than the present study with positive predictive value was 20 to $91 \%$. Positive predictive value was 60 to $80 \%$, which was higher than the present study with positive predictive value was 46 to $59 \%$. The reasons for the better indicators in that study may be due to the selection of cases with at least two years of HAART with more than $95 \%$ adherence for two full years. Here due to universal availability of second line ART in the national program, the minimum duration of HAART was reduced from 2 years to 6 months and adherence of HAART to be more than $95 \%$ in the last six months was enough to screen for viral load with immunological failure.

The longer duration of HAART and more than 95\% adherence during the whole period will increase the sensitivity and positive predictive value of each immunological criterion. CD4 falling more than $50 \%$ criteria had sensitivity of $81 \%$ for finding virological failure in the old study. In this study, CD4 falling more than $50 \%$ criteria had higher sensitivity of $91 \%$ for finding virological failure. The reason may be as discussed earlier, this criterion had higher frequency than the other two.

When comparing the ODDS ratio, CD4 falling more than $50 \%$ criteria in this study was doubled from 2.4 to 4.4 with significant P-value of 0.0004 . For CD4 falling below baseline criteria, the ODDS ratio was lowered from 1.6 to 0.8 and for CD4 persistently below hundred criteria the ODDS ratio was lowered from 2.3 to 1.6 without statistical significance. Starting of HAART at higher CD4 and fewer patients with CD4 below 100 may be the reasons for this fall in ODDS ratio of these criteria.

\section{CONCLUSIONS}

The sensitivity, specificity and positive predictive value of the immunological criteria was lower while comparing previous studies in India with relaxation of adherence and eligible immunological criteria for target viral load screening for treatment failure of first line. CD4 falling more than $50 \%$ criteria can alone be used to screen viral load for treatment failure. Stress on adherence for the whole duration of HAART rather than last 6 months may improve the immunological criteria sensitivity.

\section{REFERENCES}

1. NACO Ministry of health and family welfare. Government of India. Operational guidelines for first line ART program 2008.

2. National guidelines on second-line and alternative firstline ART for adults and adolescents May 2013. http://naco.gov.in/upload/Publication/2014/National\% 20Guidelines $\% 20$ on $\% 20$ Secondline $\% 20$ and $\% 20$ Alternative $\% 20$ Firstline\%20ART\%20For\%20Adults\%20and\%20Adolescent s\%20May\%202013.pdf 
3. Hosseinipour M, van Oosterhout J, Weigel R, et al. The SAFEST 2 study team (2009) validating clinical and immunological definitions of antiretroviral treatment failure in Malawi. The $4^{\text {th }}$ IAS conference on HIV Pathogenesis, treatment and prevention. Sydney 2009:22-5.

4. Anude CJ, Eze E, Onyegbutulem HC, et al. Immunovirologic outcomes and immuno-virologic discordance among adults alive and on anti-retroviral therapy at 12 months in Nigeria. BMC Infect Dis 2013;13(1):113.

5. Rawizza HE, Chaplin B, Meloni ST, et al. Immunologic criteria are poor predictors of virologic outcome: implications for HIV treatment monitoring in resourcelimited settings. Clin Infect Dis 2011;53(12):1283-90. doi: 10.1093/cid/cir729.

6. Haas $\mathrm{AD}$, Keiser $\mathrm{O}$, Balestre $\mathrm{E}$, et al. Monitoring and switching of first-line antiretroviral therapy in adult treatment cohorts in sub-Saharan Africa: collaborative analysis. Lancet HIV 2015;2(7):e271-8. doi:10.1016/S2352-3018(15)00087-9.
7. De La Hoz JM, Bolaño L, Cárdenas O, et al. Characterization of treatment failure in HIV positive patients in the Colombian Caribbean region. Colomb Med (Cali) 2014;45(4):162-7.

8. Ferreyra C, Yun O, Eisenberg N, et al. Evaluation of clinical and immunological markers for predicting virological failure in a HIV/AIDS treatment cohort in Busia, Kenya. PLoS One 2012;7(11):e49834. doi: 10.1371/journal.pone.0049834.

9. Raja K, Chandrasekar C, Krishnarajasekhar OR, et al. Predicting virological failure with immunological criteria in first line ART patients in a resource poor setting. World Journal of AIDS 2014;4(4):413-21. 